\title{
Keywords
}

Acute lymphoblastic; leukemia; IKZF; BCR-ABL; ALL prognosis

(C) 2012 Elsevier Inc. All rights reserved.

Address reprint requests and correspondence: Sandeep Gurbuxani, MBBS, PhD, Department of Pathology, University of Chicago, Chicago, IL 60637. Sandeep.Gurbuxani@uchospitals.edu. 


\section{Diagnosis of acute lymphoblastic leukemia}

Acute lymphoblastic leukemia (ALL) is a disease of lymphoid precursors and is the most common cancer diagnosed in children, with greater than 3000 newly diagnosed patients under the age of 20 each year (SEER 2004-2008 data). The current WHO classification of ALL contains 3 main diagnoses: (1) B-lymphoblastic leukemia/lymphoma (B-ALL), not otherwise specified, (2) B-ALL with recurrent cytogenetic abnormalities, and (3) Tlymphoblastic leukemia/lymphoma (T-ALL). Evaluation of morphology along with immunophenotyping is sufficient for diagnosis of ALL and making the distinction between B-ALL and T-ALL. Additional cytogenetic analysis is required to establish whether a given case of B-ALL can be further subcategorized according to specific chromosomal abnormalities.

Analysis of the peripheral blood and bone marrow aspirate generally reveals cells of small to medium size with minimal cytoplasm, a high nuclear-to-cytoplasmic ratio, round to oval nuclei with smudged or coarsely reticular chromatin, and inconspicuous to variably prominent nucleoli. Less commonly, cases may consist of larger cells with more abundant cytoplasm and more variable nuclear contour and chromatin. The cytoplasm is variably basophilic and may contain some vacuoles or granules.

Tissue obtained from bone marrow biopsy is generally markedly hypercellular, although less commonly it may be normocellular and in atypical cases it can even be transiently hypocellular. Bone marrow involvement is typically diffuse and uniform at the time of presentation, although it can be focal at the time of relapse. Homogenous lymphoblasts of intermediate size and minimal cytoplasm displace normal hematopoietic elements, leaving few megakaryocytes and small collections of erythroid precursors visible. The nuclei of lymphoblasts can be round or convoluted, with the chromatin generally described as evenly dispersed or stippled, but can be somewhat condensed. Nucleoli are inconspicuous but may be prominent. Brisk mitotic activity is almost always present.

Partial or extensive necrosis can sometimes be present. A completely necrotic marrow poses a diagnostic challenge and a repeat biopsy and aspirate from the contralateral site is strongly recommended and often helpful. Reticulin fibrosis can be present and result in a dry tap. Inability to aspirate also results from a "packed" marrow. When an aspirate is not available, immunophenotypic characterization can be performed by immunohistochemistry. At our institution, when an aspirate cannot be obtained, a second core is submitted to the cytogenetic laboratory and cytogenetic evaluation is performed on material obtained from the core biopsy after disaggregation of the core.

The above discussion applies to the vast majority of cases, but atypical presentations can occur. Azurophilic granules can be seen in 5\% to $7 \%$ of cases of ALL, with the granules actually being coarser and larger than those observed in acute myeloid leukemia (AML). These cases most frequently occur in children with Down syndrome and in cases with a translocation between chromosomes 9 and $22[\mathrm{t}(9 ; 22)]$. They can be distinguished from AML by immunophenotyping and lack of myeloperoxidase staining. Some ALL cases may mimic Burkitt's lymphoma based on the presence of marked vacuolation, but the deeply 
basophilic cytoplasmic characteristic of Burkitt's lymphoma is not present. Pronounced hypereosinophilia occurs in some cases, notably in B-ALL with $t(5 ; 14)$ and in T-ALL with an 8p11.2 abnormality. Finally, some patients may have an aplastic presentation that is followed by a partial recovery and subsequent overt leukemia.

Immunophenotyping is an important adjunct to diagnosis and is helpful in confirming the diagnosis as well as lineage allocation to the leukemia. When interpreting the immunophenotype data, one should keep in mind that no single antigen is specific for any neoplasm and that combining morphologic features and a panel of antigenic markers is necessary to obtain a correct diagnosis (Table 1). In addition, the combinations of markers expressed are to some extent reflective of the normal B- and T-cell development and can be used to determine the stage of development at which the leukemia transformation happened (Table 2). In B-ALL this stage of maturation frequently correlates with the underlying cytogenetic abnormality. In T-ALL, the stage of maturation has been shown to correlate with survival in some studies. Finally, it must be pointed out that expression of myeloid antigens is seen frequently in B- and T-ALL and does not preclude the diagnosis of ALL. Similarly, B-lineage antigens can be expressed in T-ALL and vice versa. The criteria for making the diagnosis of acute leukemias of ambiguous lineage have been extensively revised in the 2008 World Health Organization (WHO) classification. The requirements for assigning more than 1 lineage to a given leukemia are summarized in Table 3. A detailed discussion of the subject is beyond the scope of this review.

\section{Current risk stratification of ALL}

Outcomes of patients with ALL have improved dramatically over the years and continue to do so, with current event-free survival (EFS) rates up to $85 \% .{ }^{1}$ An important component to the success in therapeutic approaches has been better risk stratification of patients. Initial stratification is based on the immunophenotype of the leukemic blasts and categorization of a patient as having B-ALL or T-ALL. For patients with B-ALL, white blood cell (WBC) count at diagnosis was one of the earliest identified prognostic factors and remains important as part of the National Cancer Institute risk stratification scheme. ${ }^{2}$ According to National Cancer Institute criteria, patients with B-ALL who are $>365$ days and $<10$ years of age at diagnosis and who have WBC counts $<50 \times 10^{9} / \mathrm{L}$ are considered standard risk, whereas those $\geq 10$ years of age at diagnosis or who have WBC counts $250 \times 10^{9} / \mathrm{L}$ regardless of age are considered high risk (HR). ${ }^{2}$ Initial induction therapy is guided by these criteria, with standard-risk patients receiving a 3-drug induction of vincristine, L-asparaginase, and glucocorticoids and HR patients receiving a 4-drug induction that also includes an anthracycline. Patients with T-ALL are considered HR and undergo a 4-drug induction.

Further stratification of patients with B-ALL is based upon cytogenetic analysis including chromosome number or DNA content, chromosomal rearrangements, and molecular genetic abnormalities. ${ }^{1}$ Several chromosomal abnormalities have been associated with better outcomes. These include high hyperdiploidy (ie, karyotypes with $>50$ chromosomes or DNA index $\geq 1.16$ ), trisomies of chromosomes 4 and 10 and, in some studies, 17, and translocation between chromosomes 12 and 21 [t(12;21)] resulting in the fusion gene ETV6-RUNX1. ${ }^{3-11}$ Patients with excellent responses to therapy as measured by the absence of minimal residual 
disease (MRD, discussed below), and who also have trisomies of chromosomes 4 and 10 or $\mathrm{t}(12 ; 21)$, have an EFS of greater than $90 \%$. Current approaches by some groups include attempts to modify or reduce therapy to decrease potential late effects for these patients. ${ }^{12}$

However, several chromosomal abnormalities associated with B-ALL confer a worse prognosis and indicate a possible need for more intense therapy. Patients with hypodiploid karyotypes (ie, fewer than 44 chromosomes or a DNA index $<0.81$ ), rearrangement of the $M L L$ gene located at chromosome $11 \mathrm{q} 23$, in particular $\mathrm{t}(4 ; 11)$ with the $M L L-A F 4$ fusion gene, and $t(9 ; 22)$ are considered to have inferior outcomes. ${ }^{4,13-17}$ Patients in these categories therefore undergo more intense therapy, sometimes including hematopoietic stem cell transplant in the first complete remission. Outcomes for patients with $t(9 ; 22)$ appear to be much improved, however, with the addition of imatinib, a selective tyrosine kinase inhibitor of the BCR-ABL fusion protein, to an intensive chemotherapy backbone. ${ }^{18}$ Similarly, $\mathrm{t}(1 ; 19)$ was historically considered an adverse prognostic factor, but with current intensive treatment regimens, this is no longer the case. ${ }^{19-21}$ More recently, intrachromosomal amplification of chromosome 21 (iAMP21) in the region containing the AML1 gene has been identified as a rare but recurring abnormality in childhood pre-B ALL that is associated with poor outcomes, although response to therapy may identify subsets within this group of patients at higher or lower risk of relapse. ${ }^{22-24}$ Another rare but noteworthy translocation is $t(17 ; 19)$ because these patients tend to have very resistant disease and poor outcomes. ${ }^{25,26}$

T-ALL is much less common in pediatric populations, and overall this immunophenotype is associated with worse prognosis than pre-B ALL. Patients with T-ALL are thus treated similarly to HR pre-B ALL patients, with more intensive chemotherapy, regardless of age and WBC count at presentation. Recurrent cytogenetic abnormalities are found in 50\% to $70 \%$ of cases and translocations frequently involve the T-cell receptor (TCR) $\alpha$ and $\delta$ loci at $14 \mathrm{q} 11.2$, the $\beta$ locus at $7 \mathrm{q} 35$, and the $\gamma$ locus at $7 \mathrm{p} 14-15$, with a variety of translocation partners that are either transcription factors or fusion proteins that function as oncogenes. ${ }^{27}$ Therapy for T-ALL is not modified based on these rearrangements.

After a patient has undergone treatment induction for ALL, it is necessary to evaluate response to therapy so the decision can be made to stay the initial course or to intensify treatment. This decision is currently made largely on the basis of MRD. ${ }^{28}$ MRD is defined as submicroscopic disease that is obtained using more sensitive techniques. The clinical significance of MRD has been demonstrated in both childhood and adult ALL. The presence of MRD is currently defined as the presence of $0.01 \%$ or more ALL cells with the highest predictive value during or at the end of induction. ${ }^{29}$ Currently, 3 main strategies are employed to evaluate for the presence of $\mathrm{MRD}$, including quantitative real-time polymerase chain reaction (Q-PCR) of either immunoglobulin or TCR genes, Q-PCR of oncogene fusions, and flow cytometry. All 3 methods are useful strategies and concordance between them is generally high, although for some patients there can be considerable disagreement so that 1 strategy or the other may miss meaningful disease. Nonetheless, the presence of MRD is the single most powerful prognostic marker that we have in ALL because it applies to all subgroups as defined by both clinical and laboratory markers. Therefore, optimizing MRD 
detection so as not to overlook patients with suboptimal therapeutic responses must remain a priority in future work on ALL.

\section{Moving forward-beyond the 2008 WHO classification}

In evaluating the utility of a diagnostic system, one must question how it affects both the treatment and the prognosis of the patients whom it classifies. An ideal diagnostic system will facilitate determination of appropriate therapy and reach the endpoint of improved outcomes in terms of eliminating both disease and unwanted toxicity. As mentioned above, patients with ALL are treated according to clinical indicators as well as the pathologic basis of their disease, which includes cytogenetics. The incidence of various cytogenetic abnormalities included as unique entities in the 2008 WHO classification is shown in Figure 1. Unique phenotypic features and clinical correlates associated with these cytogenetic abnormalities are included in Table 4. The utility of such specific classification and treatment selection is clearly illustrated by the remarkable improvement in prognosis of patients with $t(9 ; 22)$ since implementation of imatinib into clinical practice.

Although our current cytogenetics-based subclassification of B-ALL holds prognostic value, the differences in frequency of recurring gross chromosomal rearrangements are insufficient to explain treatment failure in ALL. ${ }^{4}$ Indeed, failure occurs across all subtypes, and most patients who fail therapy lack an established HR alteration. Moreover, many cases lack any established chromosomal aberration, and the "not otherwise specified" category remains an ill-defined, heterogeneous group of diseases. Following is a review of findings over the past several years that may hold potential for elaborating our current diagnostic criteria to improve our ability to risk stratify and to apply appropriate therapies to specific patient populations.

\section{New findings specific to B-ALL}

The current emphasis on cytogenetics in B-ALL classification is largely rooted in the high incidence of chromosomal translocations, but also in the availability, established interpretation, and reliability of karyotyping. In contrast, the larger data sets that come from more detailed genomic studies can be difficult to interpret, and techniques have only become remotely amenable to the clinical setting in recent years. Interrogating the genome at higher resolution is now possible because of improved methodology of oligonucleotide arrays. Using arrays that are able to analyze copy number using 20 to 100 nucleotide probes with patient-matched controls, we can now reliably detect copy number alterations, loss of heterozygosity, and acquired uniparental disomy in tumor samples. Over the past several years there has been intense effort by several groups to use these advanced tools of genomics to uncover genetic aberrations that may be of clinical use. The most significant findings from these studies are summarized in Table 5.

\section{BCR-ABL1-like leukemia}

ALL with $\mathrm{t}(9 ; 22)$, also known as Philadelphia ${ }^{+}\left(\mathrm{Ph}^{+}\right) \mathrm{ALL}$, is well described and known for the presence of the BCR-ABL1 fusion protein and the active kinase signaling that it produces. At least prior to the use of imatinib, $\mathrm{Ph}^{+} \mathrm{ALL}$ was considered HR disease with 
consistently poor outcome. Recently, 2 groups have independently identified HR ALL with a gene expression profile similar to that of $\mathrm{Ph}^{+} \mathrm{ALL}$, referred to as $B C R-A B L 1$-like ALL. ${ }^{30,31}$ Although patients with $B C R-A B L 1$-like gene expression profile include a higher proportion of HR patients as defined by current criteria, a substantial number of these patients would have been classified as standard or low risk, which would at least in part explain the heterogeneity in outcome of these patients. ${ }^{30}$ In addition to the gene expression profile shared with $\mathrm{Ph}^{+} \mathrm{ALL}$, these patients share a high frequency of genetic alterations in the IKZF1 gene. ${ }^{30-32}$ The similar gene expression profiles observed in $\mathrm{Ph}^{-}$and $\mathrm{Ph}^{+} \mathrm{ALL}$ cases with IKZFI mutation suggest that alternative mechanisms may drive similar kinase signaling as that driven by $\mathrm{BCR}-\mathrm{ABL} 1$ in $\mathrm{Ph}^{-}$cases.

Indeed, mutations in $J A K 1, J A K 2$, and $J A K 3$ have been recently reported in $B C R-A B L 1$-like cases. ${ }^{33}$ Further, these are frequently associated with cytokine receptor-like factor 2 (CRLF2) overexpression driven by $P 2 R y 8-C R L F 2$ fusion or IGH-CRLF2 rearrangements. ${ }^{34-36}$ Activating mutations of the JAK proteins and CRLF2 overexpression cooperate in leukemogenesis to activate the JAK-STAT signaling and may be responsible for the similarity in kinase signaling profiles observed in $\mathrm{Ph}^{+}$ALL. Importantly, CRLF2 overexpression may be of use clinically because it is a surface protein and can be detected by flow cytometry. Moreover, JAK mutations may be exploited in terms of therapy because Jak inhibitors are under investigation and could potentially be used as targeted therapy for this subset of patients, much in the way imatinib has been used in $\mathrm{Ph}^{+}$cases. ${ }^{37}$

Remarkably, most B-ALL cases harbor copy number variations or mutations that disrupt key transcription factors of the B-cell developmental program. ${ }^{38,39}$ The challenge lies in determining what mutations are of clinical use because a role in leukemogenesis does not necessarily translate to a role in risk-stratification or therapeutics. Among the genes most frequently affected are $P A X 5$ and $I K Z F 1$, with PAX5 being the most common. In contrast to $I K Z F 1, P A X 5$ mutation is very common and appears to be tightly linked to leukemogenesis based both on patient studies and on mouse models, but no association with prognosis has been demonstrated to date. ${ }^{40}$

\section{iAMP21}

Although not as extensively characterized as $B C R-A B L 1$-like leukemia, iAMP21 is seen in about $2 \%$ of pediatric B-ALL patients. ${ }^{23}$ These patients frequently present with common or pre-B-ALL immunophenotype, significantly older age, and a lower white cell count when compared with children without the abnormality. Most of these patients would fall under the standard-risk category according to current criteria. However, when treated on standard-risk protocols, these patients have inferior EFS and overall survival. Based on these observations, at least 1 pediatric cooperative group treats these patients on the HR arm.

\section{New findings specific to T-ALL}

Whereas the classification of B-ALL involves chromosomal translocations, the classification of T-ALL is based solely on morphology and immunophenotype, despite the presence of many recurrent chromosomal translocations. Studies are conflicted in terms of demonstrating prognostic significance for cytogenetics and unique immunophenotypes in 
this setting, although studies in T-ALL tend to be more difficult in this capacity because of the rarity of the disease and resulting limitation of available patient specimens. ${ }^{41-44}$ However, although no clear prognostic significance has yet been demonstrated for specific mutations, we have yet to employ potential targeted therapies to T-ALL subsets extensively enough to evaluate the utility of such targeted therapy appropriately. It is exciting to speculate that once this has been achieved, we will have much to discuss in the classification and treatment of T-ALL.

Several groups have identified gene expression signatures with prognostic relevance. For example, $H O X 11$ activation is associated with a favorable prognosis, whereas high expression of TAL1, LYL1, or HOX11L2 is associated with less robust response to therapy. ${ }^{45-47}$ Using such signatures in a clinical setting is exceedingly difficult, although recent improvements in technique hold promise that with time, RNA-based protocols may have improved clinical utility. ${ }^{48,49}$

\section{NOTCH1 and associated pathways}

No discussion of T-ALL is complete without mention of Notch1. NOTCH1 was originally identified in 1991 as translocation-associated Notch homolog 1 (Tan-1) in 3 cases of T-ALL containing $\mathrm{t}(7 ; 9)(\mathrm{q} 34 ; \mathrm{q} 34.3)$ translocations that resulted in expression of a truncated NOTCHI mRNA under the control of the TCRB promoter. ${ }^{50}$ Because of the rarity of this translocation, the broad role of Notch1 in T-ALL was underappreciated until 2004 when point mutations that stabilize the Notch1 protein were uncovered in over $50 \%$ of cases in a T-ALL series. ${ }^{51,52}$ Since that time, we have come to appreciate a central role for Notch1 in T-ALL pathogenesis because it interacts directly with a myriad of pathways and players, including c-myc, PI3K/Akt signaling, PTEN, Fbxw7, and NF- $\kappa$ B. ${ }^{53-55}$ Interactions with these other pathways is likely to be of clinical importance because the use of $\gamma$-secretase inhibitors (GSIs) has demonstrated that inhibition of Notch alone is often insufficient to eradicate cell growth in human T-ALL cell lines. ${ }^{52} \mathrm{~A}$ common feature of GSI-resistant TALL lines is a decreased level of the PTEN phosphatase, which counteracts PI3K/ Akt signaling. ${ }^{56}$ Reduced PTEN protein expression in this setting has been shown to result from mutation of the PTEN gene, but absent protein expression was also observed in cases without mutation, indicating alternative mechanisms of PTEN inhibition, at least 1 of which appears to be inhibition by reactive oxygen species. ${ }^{57}$ There are undoubtedly multiple mechanisms involved here, given the central importance of each of the players at hand.

Results vary largely in terms of appreciating a prognostic role for NOTCH1 mutation, with some reports indicating a favorable prognosis but other studies not supporting this conclusion. ${ }^{44,58-66}$ The inconsistency in results most likely stems from different populations and treatment regimens across studies and lack of a targeted approach. GSI-mediated Notch inhibition has shown remarkable success in terms of tumor regression and prolonged survival in mouse models, indicating that Notch inhibition may indeed be useful in the clinical setting. ${ }^{67}$ Efforts to address the utility of GSIs in clinical trials of T-ALL have been limited by gastrointestinal toxicity, although current efforts are underway to develop new GSIs that are better tolerated. ${ }^{68-70}$ In addition, recent data have demonstrated that combined use of GSIs and glucocorticoids is beneficial not only in reversing glucocorticoid resistance, 
but also to blunt the gastrointestinal toxicities that have been demonstrated with GSI administration alone. ${ }^{71,72}$

\section{Earliest T-cell progenitor (ETP) T-ALL and the absence of biallelic TCR $\delta$ deletion}

Flow cytometry is of course widely used in the diagnosis of leukemias, and the ease and relatively low cost of performing this technique make it quite appealing clinically. Although immunophenotype in subclassifying T-ALL has been limited, multiple groups are attempting to refine its use. Recent years have witnessed the identification of a subset of TALL cases that appears highly similar to the ETPs of the thymus, characterized by the absence of CD1a and CD8 expression, low or absent expression of CD5, expression of myeloid and/or stem cell markers in at least $25 \%$ of the lymphoblasts, and rearrangement of at least 1 TCR locus. ${ }^{73}$ In the initial report of the ETP-ALL subtype, it accounted for $12.6 \%$ of T-ALL cases and was associated with a poor response to therapy, with much higher rates of minimal residual disease and relapse at 10 years.

Similar to flow cytometry, evaluation of TCRa gene rearrangements by PCR is performed routinely in evaluating T-ALL cases, although it is generally used to demonstrate clonality or detection of MRD rather than for subclassification. Using a Q-PCR approach, Gutierrez and colleagues have recently demonstrated that the absence of biallelic TCR $\delta$ deletion is highly predictive of treatment failure. ${ }^{74}$ Of note, there is overlap between the absence of biallelic $T C R \delta$ deletion and the ETP-ALL signature, although it is still less than half of cases that share both criteria.

\section{Larger genomic effects: epigenetic changes in ALL}

Most efforts regarding classification of cancers clinically revolve around specific genetic aberrations, but advances over recent years have brought forward the possibility that methylation patterns may be as useful as specific gene mutations. For years it has been recognized that translocation of the $M L L$ gene in B-ALL is associated with dysregulation of methylation and it is thought that this is the result of dysregulated $H O X$ gene expression and activity. But data from recent years suggest that methylation patterns may be of broader interest across various ALL subtypes and may even hold prognostic significance.

Promoter hypermethylation is important in the setting of cancer because of its power to inactivate genes, especially tumor suppressors. Several groups have reported that hypermethylation is an independent risk factor for survival in the setting of ALL, mostly in B-ALL, but also in T-ALL. ${ }^{75-79}$ Among reports with prognostic significance in B-ALL are analyses addressing the MLL, $\mathrm{t}(12 ; 21), \mathrm{t}(9 ; 22)$, and high hyperdiploidy subtypes, as well as global analyses. Such analyses generally require the use of methylationspecific PCR at several promoters, which is not an ideal approach to use clinically. However, continued work has demonstrated specific mutations that are linked to other epigenetic modifications, such as mutations in the histone acetyltransferase domain of $C R E B B P .{ }^{80}$ Of note, the mutations observed in $C R E B B P$ from relapsed ALL samples altered the expression of genes that contribute to glucocorticoid resistance, an issue of great importance in ALL treatments. 
Other groups have been able to identify specific signaling pathways changed drastically by hypermethylation, as well as specific microRNAs that may become of clinical importance as we continue to expand our knowledge of microRNA function and manipulation. ${ }^{81-83}$ Moreover, the importance of hypermethylation as a predictor of prognosis generates optimism for the use of methylation inhibitors as therapeutic agents. ${ }^{75,84}$

\section{Potential for Improvements in Future Diagnostic Classifications}

Survival in ALL has improved dramatically over the years, largely because of risk stratification and the resulting ability to tailor therapy appropriately; continued improvements in risk stratification would presumably continue to improve outcomes further. Inclusion of cytogenetics information for B-ALL in the 2008 WHO classification of precursor lymphoid neoplasms was in recognition of the role of cytogenetic abnormalities in defining the biology and response to therapy in patients with ALL. Continued progress in biomedical research of ALL will ultimately dictate revision of these criteria to include more subclasses based on specific genetic abnormalities, particularly those with prognostic significance and those that can be exploited for targeted therapies. The main utility of classifying cases as having $\mathrm{t}(9 ; 22)$ stems from our ability to target those cases with imatinib. Several lines of work suggest that similar stories may be coming down the pipeline, including Ph-like BALL, which may be amenable to treatment with other specific kinase inhibitors. Specific mutations in T-ALL involving Notchl and PTEN may be useful as we continue to improve our GSI therapies so that they are better tolerated. Recognition of hypermethylation may pave the way for the use of methylation inhibitors as well. Even in the absence of a targeted treatment, it is useful to know whether a particular abnormality is associated with a worse prognosis because patients with these abnormalities can be targeted for intensified regimens. Notable examples that are not yet part of the WHO classification include the presence of iAMP21 in B-ALL or the ETP-like subset of T-ALL. Moreover, particularly for more aggressive cases, continued advances in our ability to better recognize residual cancer cells will facilitate improvements in the detection of MRD, thereby enabling us to respond more readily to inadequate treatment regimens.

\section{Acknowledgments}

The authors dedicate this review to Jim Nachman, who passed away on June 5, 2011. Dr Nachman's contribution to improving the outcome of ALL patients is unparalleled. S.G. is a recipient of American Cancer Society Institutional Research Grant ACS-IRG (IRG-58-004) and the Cancer Center Support Grant P30 CA14599.

\section{References}

1. Pui CH, Carroll WL, Meshinchi S, et al. Biology, risk stratification, and therapy of pediatric acute leukemias: an update. J Clin Oncol. 2011; 29:551-565. [PubMed: 21220611]

2. Smith M, Arthur D, Camitta B, et al. Uniform approach to risk classification and treatment assignment for children with acute lymphoblastic leukemia. J Clin Oncol. 1996; 14:18-24. [PubMed: 8558195]

3. Look AT, Roberson PK, Williams DL, et al. Prognostic importance of blast cell DNA content in childhood acute lymphoblastic leukemia. Blood. 1985; 65:1079-1086. [PubMed: 3158360]

4. Moorman AV, Ensor HM, Richards SM, et al. Prognostic effect of chromosomal abnormalities in childhood B-cell precursor acute lymphoblastic leukaemia: results from the UK Medical Research Council ALL97/99 randomised trial. Lancet Oncol. 2010; 11:429-438. [PubMed: 20409752] 
5. Trueworthy R, Shuster J, Look T, et al. Ploidy of lymphoblasts is the strongest predictor of treatment outcome in B-progenitor cell acute lymphoblastic leukemia of childhood: a Pediatric Oncology Group study. J Clin Oncol. 1992; 10:606-613. [PubMed: 1548523]

6. Harris MB, Shuster JJ, Carroll A, et al. Trisomy of leukemic cell chromosomes 4 and 10 identifies children with B-progenitor cell acute lymphoblastic leukemia with a very low risk of treatment failure: a Pediatric Oncology Group study. Blood. 1992; 79:3316-3324. [PubMed: 1596572]

7. Sutcliffe MJ, Shuster JJ, Sather HN, et al. High concordance from independent studies by the Children's Cancer Group (CCG) and Pediatric Oncology Group (POG) associating favorable prognosis with combined trisomies 4, 10, and 17 in children with NCI Standard-Risk B-precursor Acute Lymphoblastic Leukemia: a Children's Oncology Group (COG) initiative. Leukemia. 2005; 19:734-740. [PubMed: 15789069]

8. Heerema NA, Sather HN, Sensel MG, et al. Prognostic impact of trisomies of chromosomes 10, 17, and 5 among children with acute lymphoblastic leukemia and high hyperdiploidy $(>50$ chromosomes). J Clin Oncol. 2000; 18:1876-1887. [PubMed: 10784628]

9. Borkhardt A, Cazzaniga G, Viehmann S, et al. Incidence and clinical relevance of TEL/AML1 fusion genes in children with acute lymphoblastic leukemia enrolled in the German and Italian multicenter therapy trials. Associazione Italiana Ematologia Oncologia Pediatrica and the BerlinFrankfurt-Münster Study Group. Blood. 1997; 90:571-577. [PubMed: 9226156]

10. McLean TW, Ringold S, Neuberg D, et al. TEL/AML-1 dimerizes and is associated with a favorable outcome in childhood acute lymphoblastic leukemia. Blood. 1996; 88:4252-4258. [PubMed: 8943861]

11. Rubnitz JE, Downing JR, Pui CH, et al. TEL gene rearrangement in acute lymphoblastic leukemia: a new genetic marker with prognostic significance. J Clin Oncol. 1997; 15:1150-1157. [PubMed: 9060558]

12. Borowitz MJ, Devidas M, Hunger SP, et al. Clinical significance of minimal residual disease in childhood acute lymphoblastic leukemia and its relationship to other prognostic factors: a Children's Oncology Group study. Blood. 2008; 111:5477-5485. [PubMed: 18388178]

13. Chessels JM, Swansbury GJ, Reeves B, et al. Cytogenetics and prognosis in childhood lymphoblastic leukaemia: results of MRC UKALL X. Medical Research Council Working Party in Childhood Leukaemia. Br J Haematol. 1997; 99:93-100. [PubMed: 9359508]

14. Nachman JB, Heerema NA, Sather H, et al. Outcome of treatment in children with hypodiploid acute lymphoblastic leukemia. Blood. 2007; 110:1112-1115. [PubMed: 17473063]

15. Harrison CJ, Haas O, Harbott J, et al. Detection of prognostically relevant genetic abnormalities in childhood B-cell precursor acute lymphoblastic leukaemia: recommendations from the Biology and Diagnosis Committee of the International Berlin-Frankfürt-Münster study group. Br J Haematol. 2010; 151:132-142. [PubMed: 20701601]

16. Aricò M, Valsecchi MG, Camitta B, et al. Outcome of treatment in children with Philadelphia chromosome-positive acute lymphoblastic leukemia. N Engl J Med. 2000; 342:998-1006. [PubMed: 10749961]

17. Uckun FM, Nachman JB, Sather HN, et al. Poor treatment outcome of Philadelphia chromosomepositive pediatric acute lymphoblastic leukemia despite intensive chemotherapy. Leuk Lymphoma. 1999; 33:101-106. [PubMed: 10194126]

18. Schultz KR, Bowman WP, Aledo A, et al. Improved early event-free survival with imatinib in Philadelphia chromosome-positive acute lymphoblastic leukemia: a Children's Oncology Group study. J Clin Oncol. 2009; 27:5175-5181. [PubMed: 19805687]

19. Crist WM, Carroll AJ, Shuster JJ, et al. Poor prognosis of children with pre-B acute lymphoblastic leukemia is associated with the $\mathrm{t}(1-19)(\mathrm{q} 23 ; \mathrm{p} 13)$ : a Pediatric Oncology Group study. Blood. 1990; 76:117-122. [PubMed: 2364165]

20. Raimondi SC, Behm FG, Roberson PK, et al. Cytogenetics of pre-Bcell acute lymphoblastic leukemia with emphasis on prognostic implications of the $t(1 ; 19)$. J Clin Oncol. 1990; 8:1380 1388. [PubMed: 2380759]

21. Felice MS, Gallego MS, Alonso CN, et al. Prognostic impact of $t(1 ; 19) / T C F 3-P B X 1$ in childhood acute lymphoblastic leukemia in the context of Berlin-Frankfurt-Münster-based protocols. Leuk Lymphoma. 2011; 52:1215-1221. [PubMed: 21534874] 
22. Robinson HM, Broadfield ZJ, Cheung KL, et al. Amplification of AML1 in acute lymphoblastic leukemia is associated with a poor outcome. Leukemia. 2003; 17:2249-2250. [PubMed: 14523475]

23. Moorman AV, Richards SM, Robinson HM, et al. Prognosis of children with acute lymphoblastic leukemia (ALL) and intrachromosomal amplification of chromosome 21 (iAMP21). Blood. 2007; 109:2327-2330. [PubMed: 17095619]

24. Attarbaschi A, Mann G, Panzer-Grümayer R, et al. Minimal residual disease values discriminate between low and high relapse risk in children with B-cell precursor acute lymphoblastic leukemia and an intrachromosomal amplification of chromosome 21: the Austrian and German acute lymphoblastic leukemia Berlin-Frankfurt-Munster (ALL-BFM) trials. J Clin Oncol. 2008; 26:3046-3050. [PubMed: 18565891]

25. Hunger SP. Chromosomal translocations involving the E2A gene in acute lymphoblastic leukemia: clinical features and molecular pathogenesis. Blood. 1996; 87:1211-1224. [PubMed: 8608207]

26. Inukai T, Hirose K, Inaba T, et al. Hypercalcemia in childhood acute lymphoblastic leukemia: frequent implication of parathyroid hormonerelated peptide and E2A-HLF from translocation 17;19. Leukemia. 2007; 21:288-296. [PubMed: 17183364]

27. Graux C, Cools J, Michaux L, et al. Cytogenetics and molecular genetics of T-cell acute lymphoblastic leukemia: from thymocyte to lymphoblast. Leukemia. 2006; 20:1496-1510. [PubMed: 16826225]

28. Bassan R, Hoelzer D. Modern therapy of acute lymphoblastic leukemia. J Clin Oncol. 2011; 29:532-543. [PubMed: 21220592]

29. Campana D. Minimal residual disease in acute lymphoblastic leukemia. Hematol Am Soc Hematol Educ Programs. 2010; 2010:7-12.

30. den Boer ML, van Slegtenhorst M, de Menezes RX, et al. A subtype of childhood acute lymphoblastic leukaemia with poor treatment outcome: a genome-wide classification study. Lancet Oncol. 2009; 10:125-134. [PubMed: 19138562]

31. Mullighan CG, Su X, Zhang J, et al. Deletion of IKZF1 and prognosis in acute lymphoblastic leukemia. N Engl J Med. 2009; 360:470-480. [PubMed: 19129520]

32. Mullighan CG, Miller CB, Radtke I, et al. BCR-ABL1 lymphoblastic leukaemia is characterized by the deletion of Ikaros. Nature. 2008; 453:110-114. [PubMed: 18408710]

33. Mullighan CG, Zhang J, Harvey RC, et al. JAK mutations in high-risk childhood acute lymphoblastic leukemia. Proc Natl Acad Sci U S A. 2009; 106:9414-9418. [PubMed: 19470474]

34. Mullighan CG, Collins-Underwood JR, Phillips LAA, et al. Rearrangement of CRLF2 in Bprogenitor- and Down syndrome-associated acute lymphoblastic leukemia. Nat Genet. 2009; 41:1243-1246. [PubMed: 19838194]

35. Cario G, Zimmermann M, Romey R, et al. Presence of the P2RY8-CRLF2 rearrangement is associated with a poor prognosis in non-high-risk precursor B-cell acute lymphoblastic leukemia in children treated according to the ALL-BFM 2000 protocol. Blood. 2010; 115:5393-5397. [PubMed: 20378752]

36. Harvey RC, Mullighan CG, Wang X, et al. Identification of novel cluster groups in pediatric highrisk B-precursor acute lymphoblastic leukemia with gene expression profiling: correlation with genome-wide DNA copy number alterations, clinical characteristics, and outcome. Blood. 2010; 116:4874-4884. [PubMed: 20699438]

37. Pardanani A. JAK2 inhibitor therapy in myeloproliferative disorders: rationale, preclinical studies and ongoing clinical trials. Leukemia. 2008; 22:23-30. [PubMed: 17882282]

38. Kuiper RP, Schoenmakers EFPM, van Reijmersdal SV, et al. High-resolution genomic profiling of childhood ALL reveals novel recurrent genetic lesions affecting pathways involved in lymphocyte differentiation and cell cycle progression. Leukemia. 2007; 21:1258-1266. [PubMed: 17443227]

39. Mullighan CG, Goorha S, Radtke I, et al. Genome-wide analysis of genetic alterations in acute lymphoblastic leukaemia. Nature. 2007; 446:758-764. [PubMed: 17344859]

40. Iacobucci I, Lonetti A, Paoloni F, et al. The PAX5 gene is frequently rearranged in BCR-ABL1positive acute lymphoblastic leukemia but is not associated with outcome. A report on behalf of the GIMEMA Acute Leukemia Working Party. Haematologica. 2010; 95:1683-1690. [PubMed: 20534699] 
41. Pullen J, Shuster JJ, Link M, et al. Significance of commonly used prognostic factors differs for children with T cell acute lymphocytic leukemia (ALL), as compared to those with B-precursor ALL. A Pediatric Oncology Group (POG) study. Leukemia. 1999; 13:1696-1707. [PubMed: 10557041]

42. Pui CH, Behm FG, Crist WM. Clinical and biologic relevance of immunologic marker studies in childhood acute lymphoblastic leukemia. Blood. 1993; 82:343-362. [PubMed: 8329694]

43. Uckun FM, Gaynon PS, Sensel MG, et al. Clinical features and treatment outcome of childhood Tlineage acute lymphoblastic leukemia according to the apparent maturational stage of T-lineage leukemic blasts: a Children's Cancer Group study. J Clin Oncol. 1997; 15:2214-2221. [PubMed: 9196133]

44. van Grotel M, Meijerink JPP, van Wering ER, et al. Prognostic significance of molecularcytogenetic abnormalities in pediatric TALL is not explained by immunophenotypic differences. Leukemia. 2008; 22:124-131. [PubMed: 17928886]

45. Cavé H, Suciu S, Preudhomme C, et al. Clinical significance of HOX11L2 expression linked to $\mathrm{t}(5 ; 14)(\mathrm{q} 35 ; \mathrm{q} 32)$, of HOX11 expression, and of SIL-TAL fusion in childhood T-cell malignancies: results of EORTC studies 58881 and 58951. Blood. 2004; 103:442-450. [PubMed: 14504110]

46. Ferrando AA, Neuberg DS, Staunton J, et al. Gene expression signatures define novel oncogenic pathways in T cell acute lymphoblastic leukemia. Cancer Cell. 2002; 1:75-87. [PubMed: 12086890]

47. Ferrando AA, Neuberg DS, Dodge RK, et al. Prognostic importance of TLX1 (HOX11) oncogene expression in adults with T-cell acute lymphoblastic leukaemia. Lancet. 2004; 363:535-536. [PubMed: 14975618]

48. Haferlach T, Kohlmann A, Wieczorek L, et al. Clinical utility of microarray-based gene expression profiling in the diagnosis and subclassification of leukemia: report from the International Microarray Innovations in Leukemia Study Group. J Clin Oncol. 2010; 28:2529-2537. [PubMed: 20406941]

49. Cleaver AL, Beesley AH, Firth MJ, et al. Gene-based outcome prediction in multiple cohorts of pediatric T-cell acute lymphoblastic leukemia: a Children's Oncology Group study. Mol Cancer. 2010; 9:105. [PubMed: 20459861]

50. Ellisen LW, Bird J, West DC, et al. TAN-1, the human homolog of the Drosophila notch gene, is broken by chromosomal translocations in T lymphoblastic neoplasms. Cell. 1991; 66:649-661. [PubMed: 1831692]

51. Ma SK, Wan TS, Chan LC. Cytogenetics and molecular genetics of childhood leukemia. Hematol Oncol. 1999; 17:91-105. [PubMed: 10641030]

52. Weng AP, Ferrando AA, Lee W, et al. Activating mutations of NOTCH1 in human T cell acute lymphoblastic leukemia. Science. 2004; 306:269-271. [PubMed: 15472075]

53. Palomero T, Dominguez M, Ferrando AA. The role of the PTEN/AKT pathway in NOTCH1induced leukemia. Cell Cycle. 2008; 7:965-970. [PubMed: 18414037]

54. Aifantis I, Vilimas T, Buonamici S. Notches, NFkappaBs and the making of T cell leukemia. Cell Cycle. 2007; 6:403-406. [PubMed: 17329966]

55. Demarest RM, Ratti F, Capobianco AJ. It's T-ALL about Notch. Oncogene. 2008; 27:5082-5091. [PubMed: 18758476]

56. Palomero T, Sulis ML, Cortina M, et al. Mutational loss of PTEN induces resistance to NOTCH1 inhibition in T-cell leukemia. Nat Med. 2007; 13:1203-1210. [PubMed: 17873882]

57. Silva A, Yunes JA, Cardoso BA, et al. PTEN posttranslational inactivation and hyperactivation of the PI3K/Akt pathway sustain primary T cell leukemia viability. J Clin Invest. 2008; 118:37623774. [PubMed: 18830414]

58. Asnafi V, Buzyn A, Le Noir S, et al. NOTCH1/FBXW7 mutation identifies a large subgroup with favorable outcome in adult T-cell acute lymphoblastic leukemia (T-ALL): a Group for Research on Adult Acute Lymphoblastic Leukemia (GRAALL) study. Blood. 2009; 113:3918-3924. [PubMed: 19109228]

59. Breit S, Stanulla M, Flohr T, et al. Activating NOTCH1 mutations predict favorable early treatment response and long-term outcome in childhood precursor T-cell lymphoblastic leukemia. Blood. 2006; 108:1151-1157. [PubMed: 16614245] 
60. Malyukova A, Dohda T, von der Lehr N, et al. The tumor suppressor gene hCDC4 is frequently mutated in human T-cell acute lymphoblastic leukemia with functional consequences for Notch signaling. Cancer Res. 2007; 67:5611-5616. [PubMed: 17575125]

61. Park MJ, Taki T, Oda M, et al. FBXW7 and NOTCH1 mutations in childhood T cell acute lymphoblastic leukaemia and T cell non-Hodgkin lymphoma. Br J Haematol. 2009; 145:198-206. [PubMed: 19245433]

62. Baldus CD, Thibaut J, Goekbuget N, et al. Prognostic implications of NOTCH1 and FBXW7 mutations in adult acute T-lymphoblastic leukemia. Haematologica. 2009; 94:1383-1390. [PubMed: 19794083]

63. Zuurbier L, Homminga I, Calvert V, et al. NOTCH1 and/or FBXW7 mutations predict for initial good prednisone response but not for improved outcome in pediatric T-cell acute lymphoblastic leukemia patients treated on DCOG or COALL protocols. Leukemia. 2010; 24:2014-2022. [PubMed: 20861909]

64. Clappier E, Collette S, Grardel N, et al. NOTCH1 and FBXW7 mutations have a favorable impact on early response to treatment, but not on outcome, in children with T-cell acute lymphoblastic leukemia (T-ALL) treated on EORTC trials 58881 and 58951. Leukemia. 2010; 24:2023-2031. [PubMed: 20861920]

65. Mansour MR, Sulis ML, Duke V, et al. Prognostic implications of NOTCH1 and FBXW7 mutations in adults with T-cell acute lymphoblastic leukemia treated on the MRC UKALLXII/ ECOG E2993 protocol. J Clin Oncol. 2009; 27:4352-4356. [PubMed: 19635999]

66. Larson Gedman A, Chen Q, Kugel Desmoulin S, et al. The impact of NOTCH1, FBW7 and PTEN mutations on prognosis and downstream signaling in pediatric T-cell acute lymphoblastic leukemia: a report from the Children's Oncology Group. Leukemia. 2009; 23:1417-1425. [PubMed: 19340001]

67. Palomero T, Ferrando A. Therapeutic targeting of NOTCH1 signaling in T-cell acute lymphoblastic leukemia. Clin Lymphoma Myeloma. 2009; 9(suppl 3):S205-S210. [PubMed: 19778842]

68. Milano J, McKay J, Dagenais C, et al. Modulation of notch processing by gamma-secretase inhibitors causes intestinal goblet cell metaplasia and induction of genes known to specify gut secretory lineage differentiation. Toxicol Sci. 2004; 82:341-358. [PubMed: 15319485]

69. van Es JH, van Gijn ME, Riccio O, et al. Notch/gamma-secretase inhibition turns proliferative cells in intestinal crypts and adenomas into goblet cells. Nature. 2005; 435:959-963. [PubMed: 15959515]

70. Wei P, Walls M, Qiu M, et al. Evaluation of selective gamma-secretase inhibitor PF-03084014 for its antitumor efficacy and gastrointestinal safety to guide optimal clinical trial design. Mol Cancer Ther. 2010; 9:1618-1628. [PubMed: 20530712]

71. Real PJ, Tosello V, Palomero T, et al. Gamma-secretase inhibitors reverse glucocorticoid resistance in T cell acute lymphoblastic leukemia. Nat Med. 2009; 15:50-58. [PubMed: 19098907]

72. Real PJ, Ferrando AA. NOTCH inhibition and glucocorticoid therapy in T-cell acute lymphoblastic leukemia. Leukemia. 2009; 23:1374-1377. [PubMed: 19357700]

73. Coustan-Smith E, Mullighan CG, Onciu M, et al. Early T-cell precursor leukaemia: a subtype of very high-risk acute lymphoblastic leukaemia. Lancet Oncol. 2009; 10:147-156. [PubMed: 19147408]

74. Gutierrez A, Dahlberg SE, Neuberg DS, et al. Absence of biallelic TCRgamma deletion predicts early treatment failure in pediatric T-cell acute lymphoblastic leukemia. J Clin Oncol. 2010; 28:3816-3823. [PubMed: 20644084]

75. Stumpel DJPM, Schneider P, van Roon EHJ, et al. Specific promoter methylation identifies different subgroups of MLL-rearranged infant acute lymphoblastic leukemia, influences clinical outcome, and provides therapeutic options. Blood. 2009; 114:5490-5498. [PubMed: 19855078]

76. Román-Gómez J, Jiménez-Velasco A, Agirre X, et al. CpG island methylator phenotype redefines the prognostic effect of $\mathrm{t}(12 ; 21)$ in childhood acute lymphoblastic leukemia. Clin Cancer Res. 2006; 12:4845-4850. [PubMed: 16914570] 
77. Román-Gómez J, Jiménez-Velasco A, Agirre X, et al. Lack of CpG island methylator phenotype defines a clinical subtype of T-cell acute lymphoblastic leukemia associated with good prognosis. J Clin Oncol. 2005; 23:7043-7049. [PubMed: 16192589]

78. Román-Gómez J, Jiménez-Velasco A, Castillejo JA, et al. Promoter hypermethylation of cancerrelated genes: a strong independent prognostic factor in acute lymphoblastic leukemia. Blood. 2004; 104:2492-2498. [PubMed: 15198948]

79. Milani L, Lundmark A, Kiialainen A, et al. DNA methylation for subtype classification and prediction of treatment outcome in patients with childhood acute lymphoblastic leukemia. Blood. 2010; 115:1214-1225. [PubMed: 19965625]

80. Mullighan CG, Zhang J, Kasper LH, et al. CREBBP mutations in relapsed acute lymphoblastic leukaemia. Nature. 2011; 471:235-239. [PubMed: 21390130]

81. Stumpel DJPM, Schotte D, Lange-Turenhout EAM, et al. Hypermethylation of specific microRNA genes in MLL-rearranged infant acute lymphoblastic leukemia: major matters at a micro scale. Leukemia. 2011; 25:429-439. [PubMed: 21116279]

82. Román-Gómez J, Agirre X, Jiménez-Velasco A, et al. Epigenetic regulation of microRNAs in acute lymphoblastic leukemia. J Clin Oncol. 2009; 27:1316-1322. [PubMed: 19164206]

83. Román-Gómez J, Cordeu L, Agirre X, et al. Epigenetic regulation of Wnt-signaling pathway in acute lymphoblastic leukemia. Blood. 2007; 109:3462-3469. [PubMed: 17148581]

84. Ruiz-Magaña MJ, Rodríguez-Vargas JM, Morales JC, et al. The DNA-methyltransferase inhibitors zebularine and decitabine induce mitochondria-mediated apoptosis and DNA damage in p53 mutant leukemic T cells. Int J Cancer. 2011 Mar 31. epub ahead of print.

85. Okamoto R, Ogawa S, Nowak D, et al. Genomic profiling of adult acute lymphoblastic leukemia by single nucleotide polymorphism oligonucleotide microarray and comparison to pediatric acute lymphoblastic leukemia. Haematologica. 2010; 95:1481-1488. [PubMed: 20435627]

86. Paulsson K, Cazier JB, Macdougall F, et al. Microdeletions are a general feature of adult and adolescent acute lymphoblastic leukemia: Unexpected similarities with pediatric disease. Proc Natl Acad Sci U S A. 2008; 105:6708-6713. [PubMed: 18458336]

87. Yoda A, Yoda Y, Chiaretti S, et al. Functional screening identifies CRLF2 in precursor B-cell acute lymphoblastic leukemia. Proc Natl Acad Sci U S A. 2010; 107:252-257. [PubMed: 20018760]

88. Harvey RC, Mullighan CG, Chen IM, et al. Rearrangement of CRLF2 is associated with mutation of JAK kinases, alteration of IKZF1, Hispanic/Latino ethnicity, and a poor outcome in pediatric Bprogenitor acute lymphoblastic leukemia. Blood. 2010; 115:5312-5321. [PubMed: 20139093]

89. O’Neil J, Grim J, Strack P, et al. FBW7 mutations in leukemic cells mediate NOTCH pathway activation and resistance to gamma-secretase inhibitors. J Exp Med. 2007; 204:1813-1824. [PubMed: 17646409]

90. Thompson BJ, Buonamici S, Sulis ML, et al. The SCFFBW7 ubiquitin ligase complex as a tumor suppressor in T cell leukemia. J Exp Med. 2007; 204:1825-1835. [PubMed: 17646408] 


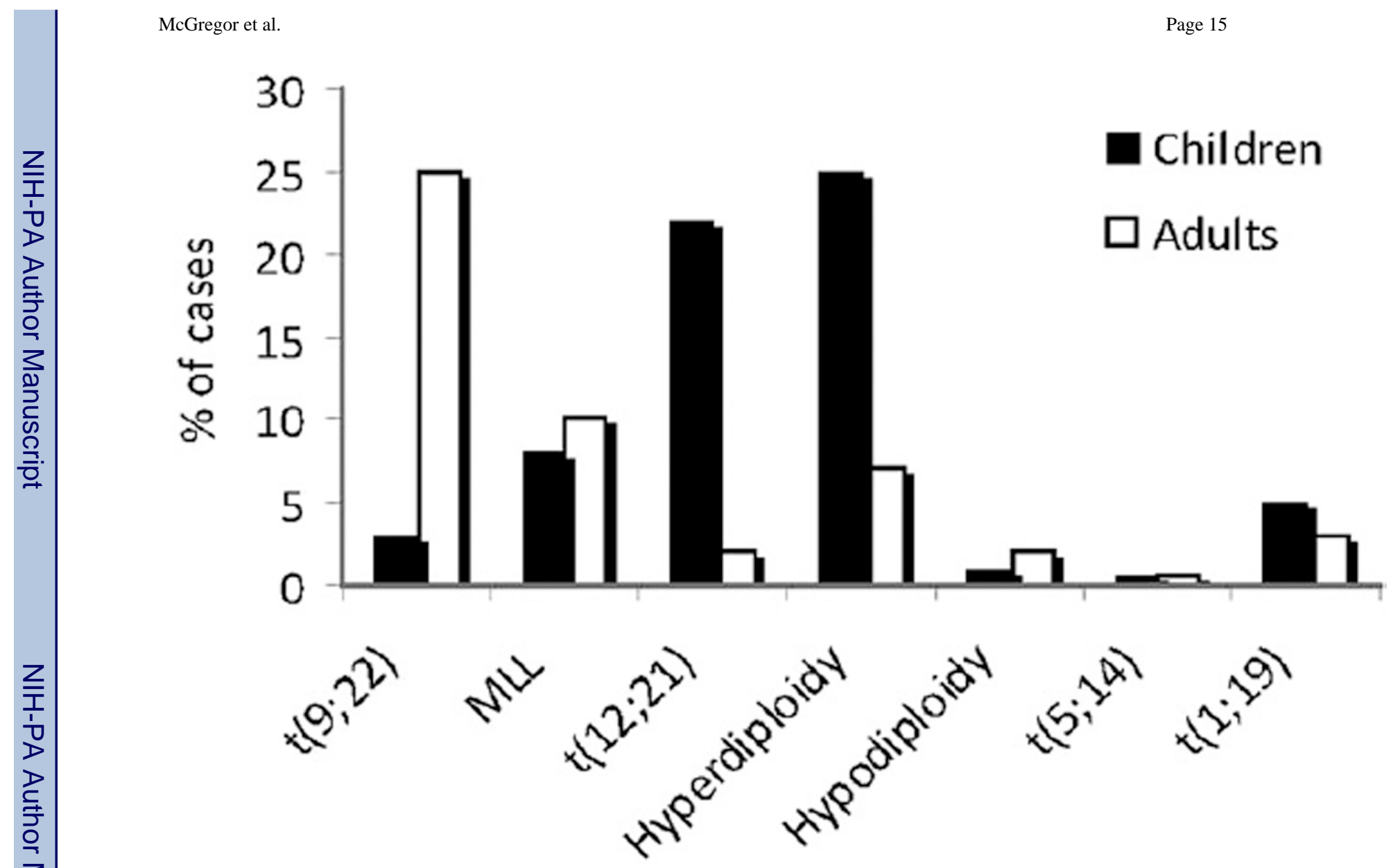

Figure 1.

Frequency of cytogenetic abnormalities recognized by the 2008 WHO classification. Bars represent the percentage of cases with the indicated abnormality within the pediatric (black) and adult (white) populations. 


\section{Table 1}

Immunophenotype of B- and T-ALL

\begin{tabular}{|c|c|c|}
\hline & Commonly positive & Variable expression \\
\hline \multirow[t]{8}{*}{ B-ALL } & CD19* & CD20 \\
\hline & $\operatorname{cCD} 22^{*}$ & CD34 \\
\hline & $\mathrm{cCD} 79 \mathrm{a}^{*}$ & CD45 \\
\hline & $\mathrm{PAX}^{\dagger}$ & CD13 \\
\hline & CD10 & CD33 \\
\hline & $\mathrm{sCD} 22$ & $\operatorname{sIg}^{\ddagger}$ \\
\hline & CD24 & \\
\hline & $\mathrm{TdT}$ & \\
\hline \multirow[t]{14}{*}{ T-ALL } & $\mathrm{cCD}{ }^{\S}$ & CD1a \\
\hline & $\mathrm{TdT}$ & $\mathrm{CD} 2$ \\
\hline & CD7 & sCD3 \\
\hline & & $\mathrm{CD} 4 \pi$ \\
\hline & & CD5 \\
\hline & & $\mathrm{CD} 8 \%$ \\
\hline & & CD10 \\
\hline & & CD34 \\
\hline & & CD99 \\
\hline & & CD19 \\
\hline & & CD33 \\
\hline & & CD79a \\
\hline & & CD117 \\
\hline & & CD56 \\
\hline
\end{tabular}

Antigens are listed approximately in order of frequency.

Abbreviations: c, cytoplasmic; s, surface.

* Almost always positive.

${ }^{\dagger}$ Most specific for B lineage, but can be positive in $\mathrm{t}(8 ; 21)$ AML.

${ }^{\dagger}$ Rarely present.

$\S$ Only marker considered lineage specific.

II Maybe coexpressed. 
Table 3

Criteria for Ambiguous Lineage Assignment

\begin{tabular}{|c|c|}
\hline Lineage & Markers \\
\hline \multirow[t]{7}{*}{ Myeloid } & Myeloperoxidase staining or \\
\hline & At least 2 markers of monocytic differentiation \\
\hline & - NSE \\
\hline & - $\quad \mathrm{CD} 11 \mathrm{c}$ \\
\hline & - $\mathrm{CD} 14$ \\
\hline & - $\quad$ CD64 \\
\hline & - Lysozyme \\
\hline \multirow[t]{2}{*}{ T lymphocyte } & - Cytoplasmic CD3 demonstrated by flow cytometry using antibody specific to the epsilon chain \\
\hline & 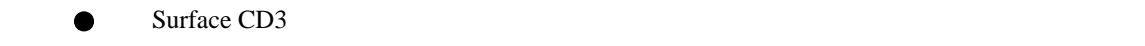 \\
\hline \multirow[t]{5}{*}{ B lymphocyte } & Strong CD19 with at least 1 additional marker or \\
\hline & Weak CD19 with at least 2 additional markers \\
\hline & - $\quad \mathrm{CD} 79 \mathrm{a}$ \\
\hline & - Cytoplasmic CD22 \\
\hline & - $\quad \mathrm{CD} 10$ \\
\hline
\end{tabular}


Table 4

Significant Features of B-ALL with Recurrent Cytogenetic Abnormalities in the 2008 WHO Classification

\begin{tabular}{|c|c|c|}
\hline Cytogenetic abnormality & Phenotype $^{\dagger}$ & Clinical correlates \\
\hline $\mathrm{t}(9 ; 22)(\mathrm{q} 33 ; \mathrm{q} 11.2)$ & $\begin{array}{l}\mathrm{CD} 19^{+}, \mathrm{CD} 10^{+}, \mathrm{CD} 25^{+}, \text {frequent } \\
\text { expression of myeloid antigens }\end{array}$ & $\begin{array}{l}\text { Seen more frequently in adults, traditionally associated } \\
\text { with extremely poor outcome, improved early event- } \\
\text { free survival with targeted therapy }\end{array}$ \\
\hline $\begin{array}{l}\mathrm{t}(\mathrm{v} ; 11 \mathrm{q} 23) \text { common fusion partners include } \\
\text { AF4 (4q21), ENL (19p13) }\end{array}$ & $\begin{array}{l}\mathrm{CD} 19^{+}, \mathrm{CD} 10^{-}, \text {aberrant } \\
\text { expression of myeloid antigen } \\
\text { CD15 }\end{array}$ & $\begin{array}{l}\text { Frequent presentation with high white cell count, } \\
\text { central nervous system involvement }\end{array}$ \\
\hline $\begin{array}{l}\mathrm{t}(12 ; 21)(\mathrm{p} 13 ; \mathrm{q} 22) \text { cryptic translocation, } \\
\text { requires fluorescent in situ hybridization }\end{array}$ & $\begin{array}{l}\mathrm{CD} 19^{+} \mathrm{CD} 10^{-}, \text {aberrant expression } \\
\text { of myeloid antigen } \mathrm{CD} 13\end{array}$ & $\begin{array}{l}\text { Sensitive disease with favorable outcome on standard } \\
\text { therapy }\end{array}$ \\
\hline $\begin{array}{l}\text { Hyperdiploidy chromosome number }>50,<66 \\
\text { Extra copies of nonrandom chromosomes- } \\
\text { most frequently } 21, \mathrm{X}, 14 \text {, and } 4\end{array}$ & $\begin{array}{l}\mathrm{CD} 19^{+}, \mathrm{CD} 10^{+} \text {, no distinctive } \\
\text { phenotype }\end{array}$ & $\begin{array}{l}\text { Sensitive disease with favorable outcome on standard } \\
\text { therapy }\end{array}$ \\
\hline Hypodiploidy chromosome number $<46$ & $\begin{array}{l}\mathrm{CD} 19^{+}, \mathrm{CD} 10^{+}, \text {no distinctive } \\
\text { phenotype }\end{array}$ & Poor prognosis \\
\hline $\mathrm{t}(5 ; 14)(\mathrm{q} 31 ; \mathrm{q} 32)$ & $\begin{array}{l}\mathrm{CD} 19^{+}, \mathrm{CD} 10^{+}, \text {no distinctive } \\
\text { phenotype }\end{array}$ & $\begin{array}{l}\text { Reactive eosinophilia driven by IL- } 3 \text { overexpression } \\
\text { driven by the translocation, blasts may be less than } 20 \% \\
\text { in the bone marrow and undetectable in peripheral } \\
\text { blood }\end{array}$ \\
\hline $\mathrm{t}(1 ; 19)(\mathrm{q} 23 ; \mathrm{p} 13.3)$ & $\mathrm{CD} 19^{+}, \mathrm{CD} 10^{+}$, cytoplasmic $\mu+$ & $\begin{array}{l}\text { No significant association with response to therapy on } \\
\text { current protocols }\end{array}$ \\
\hline
\end{tabular}


Table 5

Prevalence of recent genetic findings described in ALL

\begin{tabular}{|llll|}
\hline & \multicolumn{2}{l}{ Frequency $(\%)$} & \\
\cline { 2 - 3 } Marker & Children & Adults & References \\
\hline B-ALL & & & \\
IKZF1 mutation or deletion & $10-30$ & $15-18$ & $31,39,85,86$ \\
CRLF2 mutation with overexpression & $7-15$ & 15 & $34,87,88$ \\
JAK & $11^{*}$ & NR & 33 \\
PAX5 & 32 & NR & 39 \\
iAMP21 & 2 & NR & 23 \\
T-ALL & & & \\
NOTCH1 & $>50^{\dagger}$ & & 52 \\
FBXW7 & $9-16^{\dagger}$ & & 89,90 \\
PTEN & $8^{\dagger} \neq$ & & 56 \\
ETP-like & 13 & NR & 73 \\
Absence of biallelic TCR $\delta$ deletion & $17^{\ddagger}$ & NR & 74 \\
B- and T-ALL & & & \\
Promoter hypermethylation & Variable & Variable & $75-80$ \\
CREBBP mutation & $18^{q}$ & NR & 80 \\
\hline
\end{tabular}

Abbreviation: NR, not reported.

* Present in around $20 \%$ of Down syndrome ALL cases.

${ }^{\dagger}$ Not specified if adult or pediatric samples.

${ }^{*}$ Loss of protein in nearly $20 \%$ of cases.

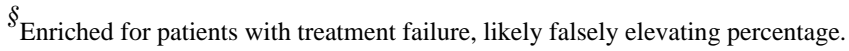

${ }^{\text {It Relapsed cases. }}$ 